\section{Fast breeder escapes veto}

A vote in West Germany's federal parliament (Bundestag) last week promises to relieve pressures on the CDU/CSU/ FDP coalition government by helping to remove the technical problems of atomic energy from political debate.

In last week's vote, the Bundestag finally agreed to lift the veto on the commissioning of the $800 \mathrm{MW}$ fast breeder reactor at Kalkar. This veto was imposed in 1978 to prevent opponents in the SPD/FDP government from killing the project completely. A commission was appointed to inquire into the safety of the installation and the majority report, published last September, found that the risks of the sodium-cooled breeder at Kalkar were no greater than those of modern pressurized water reactors. The Bundestag thus had little choice but to permit start-up in 1983, although most of the SPD used the pretext of the minority opinion to vote against lifting the veto.

From its beginning in 1971, the entire project has been bedevilled by controversy. Delays over the siting of the reactor at Kalkar were followed by the parliamentary veto. The fast breeder project has also been a catalyst to the rise of the "Green" parties as a political force. Other, technical, problems have arisen over technology licensing and in proving the safety and containment in case of accident. According to the review carried out recently by management consultants A.T. Kearney and Motor Columbus for the Ministry of Research and Technology, mismanagement has also contributed to the increased costs and delays.

The overall result is that the costs for the project have been repeatedly revised upwards at a rate well above that of inflation, and now stand at DM 6,500 million (US $\$ 2,700$ million), up by DM 1,500 million since 1980. Earlier this year, it looked as if this reactor and the other, high temperature, prototype reactor were running out of money. But the government has now found enough to keep them going for 1983, partly through cutting back other energy projects. As a result, well over 10 per cent of the 1983 research budget will be spent on the two prototype reactors.

Further development will depend on investment by the utility companies, based on the Lander. They will judge the reactors on the financial returns and it appears at present that the fast breeder will not be competitive before the end of the century. Thus there is a suspicion that a different standard is being applied to nuclear energy from that for other energy research.

On the other hand, the high temperature reactor may interest a wider spectrum of industry, although the prototype has also been subject to delays and increases in cost.

The main interest in Germany is in the use of high temperature steam for the gasi- fication of lignite and bituminous coal, of which there are extensive reserves. Combined heat and power schemes, already in use in some northern cities with conventional power stations, provide an outlet for waste heat. Finally the reactor might be used to drive thermochemical cycles for splitting water to produce hydrogen. The EEC Commission has made hydrogen a major research subject and several cycles are being studied at the Joint Research Centres and elsewhere.

J.S.Dunnett

\section{European atom treaty \\ New rules}

\section{Brussels}

France's agreement with India to supply the Tarapur nuclear power station is being questioned by officials in Brussels. The agreement may be breaking the Euratom Supply Agency's monopoly over the supply of nuclear materials which has existed since the Euratom treaty was signed in 1958 . The inquiry could be used as a way of applying pressure on France to agree to a revision of Chapter 6 of the treaty which the European Commission is proposing in order to bring it in line with the changes that have taken place in the nuclear industry since 1958 .

The new proposals are the third attempt in eight years to bring the treaty up to date. In the past both France and the United Kingdom have opposed such a move in order to protect their nuclear fuel companies, British Nuclear Fuels Limited at Sellafield (Windscale) and Cogema at Cap de la Hague. The Commission suspects that both these companies have been using their market dominance to maximize profits by rigging prices and imposing unnecessary conditions on their customers in the rest of the European Community. Customers have been persuaded not to hold stocks of reprocessed fuels or to sell them to other users and the Commission feels that it would at once be realistic to abolish the illusion of a Euratom monopoly and to insist on a genuinely free market for the nuclear fuels industry. Otherwise there may be some risk that countries such as Belgium and West Germany may decide to build their own reprocessing plants, which would lead to over-capacity in Europe.

The new rules which the Commission is putting forward would give the European Commission the power to penalize anyone imposing any restrictions on trade in nuclear materials inside the Community. Exports, on the other hand, could be contracted on a bilateral basis provided the Commission can ensure that the contract would not damage the interests of any other EEC country. But a certain solidarity amongst the EEC member states would continue to be enforced in the event of a shortage when the European Commission would undertake to share out stocks equitably. The Euratom Supply Agency, which in the past has been successful in negotiating long term uranium supply contracts with Australia, Canada and the United States, would continue to supervise and negotiate such deals. Jasper Becker

\title{
Stanford cuts comment on patent
}

\section{Washington}

Stanford University, citing "erroneous public impressions" concerning the Cohen-Boyer biotechnology patent, last week ordered the US Patent and Trademark Office to keep secret all future action on its pending application. The move came just before the patent office was expected to announce its latest action on the application, which it tentatively rejected last summer.

Normally, all actions on a patent application are secret until a patent is granted but Stanford originally waived its right to secrecy. According to Robert Rosenzweig, Stanford's vice-president for public affairs, the "central issue" in Stanford's decision to close the file was "the dispute over inventorship" (see Nature 25 November, p. 303). "We thought that had some potential for damaging people's reputations unnecessarily", he said. Dr Robert Helling, a coauthor of the key scientific paper on which the patents are based, is now claiming that he is a co-inventor; the confusion over Helling's role was cited in the patent office's tentative rejection.

Rosenzweig said that keeping the file open had been "an experiment with some risk" and that "the experiment has failed". He said, "when the application process is completed, the file will be opened for public inspection. Until then, it is better that it not emerge in piecemeal fashion."

Stanford has already sold licences to the first Cohen-Boyer patent, issued in December 1980, to 73 companies for an initial fee of $\$ 10,000$ per year. That patent, which covers the basic process for inserting foreign DNA into bacteria, is similar to the second one, now pending, which covers the transformed bacteria products. Thus there has been concern that the flaws the patent of fice cited in the second patent could invalidate the first patent. The licensees have discussed the possibility that Stanford should open the first patent for reexamination and meanwhile hold the licence fees in escrow. Rosenzweig said that the licensees would be kept informed of the progress of the second patent.
Stephen Budiansky 